\title{
PEMERINTAH SEBAGAI SUBJEK HUKUM PERDATA DALAM KONTRAK PENGADAAN BARANG ATAU JASA
}

\author{
Oleh: Sarah S. Kuahaty
}

\begin{abstract}
Dalam pembagiannya subjek hukum Perdata terdiri atas manusia (naturlijkperson) dan badan hukum (rechtperson). Tetapi dalam perkembangannya, ternyata pemerintah yang adalah lembaga publik dapat juga melakukan tindakan hukum perdata, hal ini dapt dibuktikan dengan terlibatnya pemerintah sebagai salah satu pihak dalam kontrak pengadaan barang atau jasa. Berdasarkan hasil penelusuran ternyata bahwa, ketika pemerintah bertindak dalam lapangan keperdataan dan tunduk pada peraturan hukum perdata, maka pemerintah bertindak sebagai wakil dari badan hukum bukan wakil dari jabatan, sehingga tindakan pemerintah tersebut adalah tindakan badan hukum.
\end{abstract}

Keyword: pemerintah, subjek hukum.

\section{A. LATAR BELAKANG.}

Hukum dalam klasifikasinya terbagi atas hukum publik dan hukum privat. Hukum publik yaitu hukum yang mengatur hubungan antara negara dengan alat-alat perlengkapan negara atau negara dengan warga negara. Hukum privat yaitu hukum yang mengatur hubungan antara satu orang dengan orang lain atau subjek hukum lain dengan menitikberatkan pada kepentingan perseorangan. Berdasarkan pengertiannya, maka subjek hukum perdata terdiri atas orang dan badan hukum.

Tidak dapat di pungkiri bahwa pemerintah dalam kegiatan sehari-hari melakukan tindakan-tindakan bisnis dengan pihak non-pemerintah. Pemerintah misalnya perlu membeli barang atau jasa (government procurement) dalam rangka menjalankan fungsinya sehari-hari. Barang atau jasa yang dibutuhkan dari yang sederhana seperti alat tulis kerja, sampai dengan pembeliaan pesawat udara, Pembangunan Gedung dan jembatan ataupun juga peralatan perang guna menunjang pertahanan dan keamanan negara. Sedangkan jasa yang dibutuhkan oleh pemerintah dapat berupa jasa konsultansi, dan lain-lain.

Dalam memenuhi kebutuhannya tersebut, tentunya pemerintah harus mengikuti prosedur pengadaan sebagaimana telah diatur dalam Peraturan Presiden Nomor 54 Tahun 2010 Tentang Pengadaan Barang/Jasa Pemerintah. Pengadaan Barang/Jasa Pemerintah adalah kegiatan untuk memperoleh Barang/Jasa oleh Kementerian/Lembaga/Satuan Kerja Perangkat Daerah/Institusi lainnya yang prosesnya dimulai dari perencanaan kebutuhan sampai diselesaikannya seluruh kegiatan untuk memperoleh Barang/Jasa.

Prosedur pengadaan barang/jasa dapat dilakukan dengan menggunakan penyedia barang/jasa dan juga dapat dilaksanakan sendiri oleh pemerintah secara swakelola. Oleh karenanya agar prosedur pengadaan tersebut mempunyai kekuatan hukum yang tetap dan mengikat bagi para pihak yang terlibat di dalamnya, maka hubungan hukum yang tercipta haruslah dibingkai dengan hukum yang dikenal 
dengan kontrak. dalam pasal 1 angka 22 Perpres 54 Tahun 2010 disebutkan bahwa yang dimaksudkan dengan kontrak adalah perjanjian tertulis antara Pejabat Pembuat Komitmen $(\mathrm{PPK})^{1}$ dengan Penyedia Barang/Jasa atau pelaksana Swakelola.

Secara sederhana kontrak dapat digambarkan sebagai suatu perjanjian antara dua atau lebih pihak yang mempunyai nilai komersial tertentu. Sebagaimana layaknya sebuah perjanjian, dalam sebuah kontrak para pihak yang mengikatkan diri adalah subjek hukum. Adapun yang dimaksud dengan subjek hukum disini adalah subjek hukum perdata. Apabila telah di pahami bahwa yang dimaksud para pihak dalam kontrak adalah subjek hukum perdata, maka timbul pertanyaan apakah mungkin pemerintah yang tidak biasanya di persepsikan sebagai subjek hukum perdata tetapi subjek hukum publik dapat menjadi salah satu pihak dalam sebuah kontrak pengadaan barang atau jasa?

\section{B. PEMBAHASAN}

\section{Subjek Hukum perdata}

Manusia adalah pendukung hak dan kewajiban. Lazimnya dalam hukum di kenal dengan istilah subjek hukum. Tetapi manusia bukanlah satu-satunya subjek hukum. Karena masih ada subjek hukum lainnya yaitu segala sesuatu yang menurut hukum dapat mempunyai hak dan kewajiban, termasuk apa yang di sebut badan hukum. ${ }^{2}$ Istilah subjek Hukum berasal dari terjemahan rechsubject (Belanda) atau law of subject (Inggris).

Subjek Hukum mempunyai kedudukan dan peranan yang sangat penting

1 Beradasarkan ketentuan pasal 1 angka 7 Perpres 54 Tahun 2010, maka yang dimaksudkan dengan Pejabat Pembuat Komitmen yang selanjutnya disebut PPK adalah pejabat yang bertanggung jawab atas pelaksanaan Pengadaan Barang/Jasa.

Chidir Ali, Badan Hukum, Alumni, Bandung, 2005, hal.4 di dalam bidang hukum, khususnya hukum keperdataan, karena subjek hukum itulah nantinya yang dapat mempunyai wewenang hukum (rechtsbevoegheid). Didalam berbagai literatur di kenal 2 (dua) macam subjek hukum yaitu manusia (naturlijkperson) dan badan hukum (rechtperson).

Pada Dasarnya manusia mempunyai hak sejak di lahirkan, namun tidak semua manusia mempunyai kewenangan dan kecakapan untuk melakukan perbuatan hukum. Orang yang dapat melakukan perbuatan hukum adalah orang-orang yang telah dewasa dan/atau sudah kawin. Sedangkan orang yang tidak cakap melakukan perbuatan hukum adalah orang yang belum dewasa, orang yang di taruh di bawah pengampuan dan seorang wanita yang bersuami (Pasal 1330 BW). Tapi dalam perkembangannya seorang istri dapat juga mealakukan perbuatan hukum sendiri, baik untuk membuat perjanjian maupun untuk menghadap ke pengadilan. ${ }^{3}$

Selain naturlijkperson sebagai subjek hukum, maka subjek hukum lainnya adalah badan hukum rechtperson. Ketentuan tentang badan hukum dalam BW hanya terdapat dalam 13 pasal yakni pasal 1653 sampai dengan pasal 1665 BW. Dalam pengaturannya tidak ada satu pasal pun yang memberikan pengertian badan hukum. Pengertian badan hukum hanya dapat di lihat dalam doktrin ilmu hukum. Menurut Rochmat Soemitro rechtperson adalah suatu badan yang dapat mempunyai harta kekayaan, hak serta kewajiban seperti orang pribadi. ${ }^{4}$ Menurut Sri Soedewi Masjchoen sebagimana di kutip dari Salim H. S berpendapat bahwa yang di maksudkan dengan badan hukum adalah Kumpulan orang-orang yang bersama-sama bertujuan untuk mendirikan suatu badan, yaitu (1)

\footnotetext{
3 Lihat SEMA Nomor 3 tahun 1963 jo Pasal 31 Undang-Undang Nomor 1 Tahun 1974 Tentang Perkawinan

4 Rochmat Soemitro, Hukum Perseroan Terbatas, Yayasan dan Wakaf, Eresco, Bandung,1993, hal.10
} 
berwujud himpunan, dan (2) harta kekayaan yang di sendirikan untuk tujuan tertentu, dan ini di kenal dengan yayasan. ${ }^{5}$ Dari kedua pendapat ini, maka jelas terlihat bahwa sebuah badan hukum selalu berkaitan dengan harta kekayaan, yang berada dalam ranah hukum privat.

\section{Kedudukan Pemerintah}

Dalam perspektif hukum publik negara adalah organisasi jabatan. Di antara jabatan-jabatan kenegaraan ini terdapat jabatan pemerintahan, yang menjadi objek hukum administrasi negara. Menurut $\mathbf{P}$. Nicolai ada beberapa ciri yang terdapat pada jabatan atau organ pemerintahan yaitu: ${ }^{6}$

1. Het bestuursorgaan oefent de bevoegdheid uit op eigen naam en verantwoordelijkheid. Dat laatste betekent dat als politiek of ambtelijk verantwoording moet worden algelegd, of als het bestuur zich tegenover de rechter heeft te veranswoorden voor de wijze van uitoefening van de bevoegdheid, het bestuursorgaan drager is van de verantwoordingsplicht (Organ pemerintahan menjalankan wewenang atas nama dan tanggungjawab sendiri, yang dalam pengertian moderen diletakkan sebagai pertanggungjawaban politik dan kepegawaian atau tanggungjawab pemerintah sendiri di hadapan Hakim. Organ pemerintah adalah pemikul kewajiban tanggungjawab).

2. Woord een bevoegdheidsuitoefening via een bestuursrechtelijke voorziening, dat wil zeggen in bezwaar of beroep, bestreden, dan treedt het bestuursorgaan als verwerende procespartij op (Pelaksanaan wewenang dalam rangka menjaga dan

Salim H. S. Pengantar Hukum Perdata tertulis (BW), Sinar Grafika, Jakarta, 2008, hal.25

6 Philipus M. Hadjon, et.all., Pengantar Hukum Administrasi Indonesia, Gadjah Mada University Press, Yogyakarta, 2002, hal. 150. mempertahankan norma hukum administrasi, organ pemerintahan dapat bertindak sebagai pihak tergugat dalam proses peradilan, yaitu dalam hal ada keberatan, banding atau perlawanan).

3. Bestuursorganen kunnen, zoals reeds aan de orde is gekomen, in een bestuursrechtelijke voorziening ook als klagende partij optreden (Di samping sebagai pihak tergugat, organ pemerintahan juga dapat tampil menjadi pihak yang tidak puas, artinya sebagai penggugat).

4. Bestuursorganen bezitten in het algemeen geen eigen vermogen. Wel maken die organen deel uit van een privaatrechtelijke rechtspersoon met vermoegen. Zo zijn de burgemesster, het college van $B$ en $W$ en de gemeenteraad organen van het openbare lichaam "de op grond van art. 2:1 BW privaatrechtelijke rechtspersoonlijkheid toekomt. Besluit de rechter om aan het bestuur een dwangsom op te leggen of om het bestuur tot vergoeding van schade te veroordelen, dan zal hij aan een privaatrechtelijke rechtspersoon (als drager van vermogen) de vereiste verplichtingen moeten opleggen (Pada prinsipnya organ pemerintahan tidak memiliki harta kekayaan sendiri. Organ pemerintahan merupakan bagian (alat) dari badan hukum menurut hukum privat dengan harta kekayaannya. Jabatan Bupati atau Walikota adalah organ-organ dari badan umum "Kabupaten". Berdasarkan aturan hukum badan umum inilah yang dapat memiliki harta kekayaan, bukan organ pemerintahannya).

Meskipun jabatan pemerintahan ini dilekati dengan hak dan kewajiban atau diberi wewenang untuk melakukan tindakan hukum, namun jabatan tidak dapat bertindak sendiri. Jabatan dapat melakukan perbuatan hukum, yang dilakukan melalui perwakilan yaitu pejabat.

Antara jabatan dengan pejabat memiliki hubungan yang erat, namun di 
antara keduanya sebenarnya memiliki kedudukan hukum yang berbeda atau terpisah dan diatur dengan hukum yang berbeda. Jabatan diatur oleh hukum tata negara dan hukum administrasi, sedangkan pejabat diatur dan tunduk pada hukum kepegawaian. Di samping itu, tampak bahwa pejabat menampilkan dirinya dalam dua kepribadian yaitu selaku pribadi dan selaku personifikasi dari organ, yang berarti selain diatur dan tunduk pada hukum kepegawaian juga tunduk pada hukum keperdataan khusus dalam kapasitasnya selaku individu atau pribadi. Tindakan hukum jabatan pemerintah dijalankan oleh pemerintah. Dengan demikian, kedudukan hukum pemerintah berdasarkan hukum publik adalah wakil dari jabatan pemerintahan.

\section{Pemerintah Sebagai Subjek Hukum Perdata Dalam Kontrak Pengadaan Barang Atau Jasa}

Dalam pengadaan barang barang atau jasa, pemerintah akan membingkai hubungan hukum dengan penyedia barang atau jasanya dalam sebuah kontrak pengadaan barang atau kontrak pengadaan jasa. Dengan kata lain pemerintah menjadi salah satu pihak dalam sebuah kontrak. Dalam konteks demikian pemerintah tidak dapat memposisikan dirinya lebih tinggi dari penyedia barang atau jasanya, walaupun pemerintah merupakan lembaga yang melakukan tindakan-tindakan yang bersifat mengatur (regulator). Hal ini dikarenakan dalam hukum perjanjian para pihak mempunyai kedudukan yang sama, sebagaimana tercermin dalam pasal 1338 BW. Dalam konteks demikian, maka baik pemerintah maupun penyedia barang atau jasa sama-sama memilki kedudukan yang sejajar dalam pemenuhan hak dan kewajiban yang tertuang di dalam kontrak yang di sepakati.

Keterlibatan pemerintah dalam suatu hubungan kontraktual ini berbeda dengan kontrak komersial pada umumnya, karena karakteristik dari kontrak ini tidak murni lagi merupakan tindakan hukum privat tetapi juga sudah ada campuran hukum publik di dalamnya. Keterlibatan pemerintah dalam kontrak ini menunjukan tindakan pemerintah tersebut diklasifikasikan dalam tindakan pemerintahan yang bersifat keperdataan. Berkenaan dengan tindakan hukum keperdataan dalam penyelenggaraan urusan pemerintahan, Philipus M. Hadjon menyatakan bahwa: ${ }^{7}$

"Sekalipun tindakan hukum keperdataan untuk urusan pemerintahan oleh badan atau pejabat tata usaha negara dimungkinkan, bukan tidak mungkin pelbagai ketentuan hukum publik (hukum tata usaha negara) akan menyusup dan mempengaruhi peraturan hukum perdata. Contohnya beberapa ketentuan peraturan perundang-undangan yang secara khusus mengatur tata cara atau prosedur tertentu yang harus ditempuh berkenaan upaya perbuatan hukum keperdataan yang dilakukan oleh badan atau pejabat tata usaha negara."

Pemerintah sebagai salah satu subjek hukum dalam tindakan perdata, maka pemerintah merupakan badan hukum, karena menurut Apeldoorn negara, propinsi, kotapraja dan lain sebaginya adalah badan hukum. Hanya saja pendiriannya tidak dilakukan secara khusus, melainkan tumbuh secara historis. ${ }^{8}$ Pemerintah dianggap sebagai badan hukum, karena pemerintah menjalankan kegiatan komersial (acts jure gestionisi).

Pemerintah sebagai badan hukum juga dapat di temukan dalam pasal 1653 BW, yang menyebutkan:

"Selain perseroan perdata sejati, perhimpunan orang-orang sebagai badan hukum juga di akui undangundang, entah badan hukum itu diadakan oleh kekuasaan umum atau di

\footnotetext{
Philipus M. Hadjon, et.all., Ibid, hal. 167.

8 L. J van Apeldoorn, Pengantar Ilmu Hukum, Noor Komala, Jakarta, 1982, h.164
} 
akui sebagai demikian, entah pula badan hukum itu di terima sebagai yang di perkenankan atau telah didirikan untuk suatu maksud tertentu yang tidak bertentangan dengan undang-undang atau kesusilaan".

Cara pendirian badan hukum tersebut yang digariskan oleh pasal $1653 \mathrm{BW}$, maka menurut Chidir Ali ada 3 (tiga) bentuk badan hukum, yaitu: ${ }^{9}$

(a) Badan hukum yang diadakan oleh kepentingan umum (pemerintah atau negara), termasuk di dalamnnya badanbadan hukum publik seperti propinsi, daerah swapraja, kabupaten dan sebagainya;

(b) Badan hukum yang diakui oleh kekuasaan umum;

(c) Badan hukum yang diperkenankan dan yang didirikan dengan tujuan tertentu yang tidak bertentangan dengan undang-undang atau kesusilaan.

Dari ketiga jenis badan hukum yang disebutkan, bentuk yang ketiga ini disebut juga badan hukum dengan konstruksi keperdataan.

Selanjutnya pemerintah selaku badan hukum dapat melakukan tindakan perdata sebagimana di tegaskan dalam pasal 1654 BW, yang menyebutkan:

"Semua badan hukum yang berdiri dengan sah, begitu pula orang-orang swasta, berkuasa untuk melakukan perbuatanperbuatan perdata, tanpa mengurangi perundang-undangan yang mengubah kekuasaan itu, membatasi atau menundukkannya kepada tata cara tertentu".

Sebagai subjek hukum perdata pemerintah dapat mengikatkan dirinya dengan pihak ketiga dalam hal ini penyedia barang ataiu jasa. Hak dan kewajiban dari masing-masing pihak, sampai kepada prosedur pelaksanaannya harus diatur secara jelas dan dituangkan dalam bentuk kontrak.

Jenis kontrak yang melibatkan pemerintah sebagai salah satu pihak pada

\footnotetext{
9 Chidir Ali, Op. cit, h. 60
}

dasarnya dapat dibedakan menjadi dua jenis yakni: kontrak komersial (commercial contract) dan kontrak kebijaksanaan (beleidsoverenkomst). Kontrak komersial dapat dibedakan menjadi dua jenis yakni kontrak pengadaan barang dan jasa (procurement contract) dan kontrak non pengadaan (non-procurement contract). ${ }^{10}$

Keterlibatan pemerintah dalam kontrak sebagai upaya melaksanakan pelayanan publik dalam bentuk pembangunan infrastruktur tergolong dalam kontrak komersial, karena pembangunan infrastrukstur merupakan bagian dari kontrak pengadaan barang dan jasa (procrument contract).

Dalam pengadaan barang barang atau jasa, pemerintah akan membingkai hubungan hukum dengan penyedia barang atau jasanya dalam sebuah kontrak pengadaan barang atau kontrak pengadaan jasa. Dengan kata lain pemerintah menjadi salah satu pihak dalam sebuah kontrak. Kedudukan pemerintah dalam pergaulan hukum keperdataan tidak berbeda dengan subjek hukum privat lainnya yakni orang maupun badan hukum, Sebagai subjek hukum perdata pemerintah dapat mengikatkan dirinya dengan pihak ketiga dalam hal ini penyedia barang ataiu jasa. Hak dan kewajiban dari masing-masing pihak, sampai kepada prosedur pelaksanaannya harus diatur secara jelas dan dituangkan dalam bentuk kontrak.

Kedudukan Pemerintah dalam kontrak juga tidak memiliki kedudukan yang istimewa, dan dapat menjadi pihak dalam sengketa keperdataan dengan kedudukan yang sama dengan seseorang atau badan hukum perdata dalam peradilan umum.

10 Yohanes Sogar Simamora, Pembentukan Dan Pelaksanaan Kontrak Pengadaan, Seminar Nasional Kontrak Pengadaan Barang dan Jasa Oleh Pemerintah, Fakultas Hukum Universitas Airlangga, 2006, h.1. 


\section{P E N U T U P}

\section{Kesimpulan}

Subjek Hukum mempunyai kedudukan dan peranan yang sangat penting di dalam bidang hukum, khususnya hukum keperdataan, karena subjek hukum itulah nantinya yang dapat mempunyai wewenang hukum (rechtsbevoegheid) untuk melakukan perbuatan hukum. Dikenal 2 (dua) macam subjek hukum perdata yakni manusia (naturlijk person) dan badan hukum (recht person).

Negara dalam perspektif hukum perdata adalah sebagai badan hukum publik. Bila berdasarkan hukum publik negara adalah organisasi jabatan atau kumpulan dari organ-organ kenegaraan, yang di dalamnya terdapat organ pemerintahan, maka berdasarkan hukum perdata, negara adalah kumpulan dari badan-badan hukum, yang di dalamnya terdapat badan pemerintahan.

Tindakan hukum badan pemerintahan dilakukan oleh pemerintah sebagaimana manusia dan badan hukum privat terlibat dalam lalu lintas pergaulan hukum. Pemerintah menjual dan membeli, menyewa dan menyewakan, menggadai dan menggadaikan, membuat perjanjian, dan mempunyai hak milik. Ketika pemerintah bertindak dalam lapangan keperdataan dan tunduk pada peraturan hukum perdata, pemerintah bertindak sebagai wakil dari badan hukum, bukan wakil dari jabatan.

\section{Saran}

Berdasarkan hasil penulisan ini, maka dapat disarankan agar baik pemerintah maupun para penegak hukum kiranya lebih memahami kedudukan pemerintah dalam kontrak pengadaan barang atau jasa, karena pemerintah walaupun sebuah lembaga publik tetapi dapat melakukan perbuatan privat, apabila timbul permasalahan akibat hubungan hukum yang dilakukan, maka Kedudukan Pemerintah dapat menjadi pihak dalam sengketa keperdataan dengan kedudukan yang sama dengan seseorang atau badan hukum perdata dalam peradilan umum.

\section{DAFTAR PUSTAKA}

Chidir Ali, Badan Hukum, Alumni, Bandung, 2005;

Daliyo, J. B, et.all, Pengantar Ilmu Hukum, PT. Gramedia Pustaka Utama, Jakarta, 1992;

Philipus M. Hadjon, et.all., Pengantar Hukum Administrasi Indonesia, Gadjah Mada University Press, Yogyakarta

L. J van Apeldoorn, Pengantar Ilmu Hukum, Noor Komala, Jakarta, 1982;

Salim H. S. Pengantar Hukum Perdata tertulis (BW), Sinar Grafika, Jakarta, 2008;

Simamora,Yohanes Sogar, Pembentukan

Dan Pelaksanaan Kontrak Pengadaan, Seminar Nasional Kontrak Pengadaan Barang dan Jasa Oleh Pemerintah, Fakultas Hukum Universitas Airlangga, 2006;

Soemitro, Rochmat, Hukum Perseroan Terbatas, Yayasan dan Wakaf, Eresco, Bandung,1993 